Article

\title{
Angiotensin Converting Enzyme (ACE)-Peptide Interactions: Inhibition Kinetics, In Silico Molecular Docking and Stability Study of Three Novel Peptides Generated from Palm Kernel Cake Proteins
}

\author{
Mohammad Zarei ${ }^{1, * \mathbb{D}}$, Najib Bin Zainal Abidin ${ }^{2}$, Shehu Muhammad Auwal ${ }^{3}$, \\ Shyan Yea Chay ${ }^{2}$, Zaibunnisa Abdul Haiyee ${ }^{1}$, Adi Md Sikin ${ }^{1}$ and Nazamid Saari ${ }^{2, * \mathbb{D}}$ \\ 1 Department of Food Science and Technology, School of Industrial Technology, Faculty of Applied Sciences, \\ Universiti Teknologi MARA, Shah Alam 40450, Selangor, Malaysia \\ 2 Department of Food Science, Faculty of Food Science and Technology, Universiti Putra Malaysia, \\ Serdang 43400, Selangor, Malaysia \\ 3 Department of Biochemistry, Faculty of Basic Medical Sciences, Bayero University, Kano 700231, Nigeria \\ * Correspondence: mzarei.mail@gmail.com (M.Z.); nazamid@upm.edu.my (N.S.); Tel.: +60-3-9769-8385 (M.Z.)
}

Received: 25 July 2019; Accepted: 7 August 2019; Published: 4 October 2019

check for

\begin{abstract}
Three novel peptide sequences identified from palm kernel cake (PKC) generated protein hydrolysate including YLLLK, WAFS and GVQEGAGHYALL were used for stability study against angiotensin-converting enzyme (ACE), ACE-inhibition kinetics and molecular docking studies. Results showed that the peptides were degraded at different cleavage degrees of $94 \%, 67 \%$ and $97 \%$ for YLLLK, WAFS and GVQEGAGHYALL, respectively, after $3 \mathrm{~h}$ of incubation with ACE. YLLLK was found to be the least stable (decreased ACE-inhibitory activity) compared to WAFS and GVQEGAGHYALL (increased ACE-inhibitory activity). YLLLK showed the lowest $K_{i}(1.51 \mathrm{mM})$ in inhibition kinetics study when compared to WAFS and GVQEGAGHYALL with $\mathrm{K}_{\mathrm{i}}$ of $2 \mathrm{mM}$ and $3.18 \mathrm{mM}$, respectively. In addition, ACE revealed the lowest $K_{\mathrm{m}}^{\mathrm{app}}$ and $V_{\max }^{\mathrm{app}}$ and higher catalytic efficiency (CE) in the presence of YLLLK at different concentrations, implying that the enzyme catalysis decreased and hence the inhibition mode increased. Furthermore, YLLLK showed the lowest docking score of -8.224 and seven interactions with tACE, while peptide GVQEGAGHYALL showed the higher docking score of -7.006 and five interactions with tACE.
\end{abstract}

Keywords: peptide; kinetics; molecular docking; angiotensin converting enzyme inhibitory activity

\section{Introduction}

Bioactive peptides are protein-based compounds having amino acid residues in the range of 2 to 20 and possess numerous biological effects on human health. They are produced from different protein sources via a variety of production approaches such as the use of proteolytic enzymes, fermentation using different bacteria or fungi and digestion of food proteins after their consumption [1,2]. The most common biological roles of bioactive peptides which have been previously reported in numerous studies are antihypertensive, antioxidative, anti-thrombotic, anti-carcinogenic, immunomodulatory effects as well as anti-inflammatory and anti-aging activities [3-8].

Antihypertensive peptides are natural alternatives to synthetic angiotensin-converting enzyme (ACE) inhibitors, of which the latter would produce mild to severe adverse side effects such as dry cough, dizziness, headaches and fatigue. Although the ACE inhibitory activity of bio-peptides are lower than synthetic ACE inhibitors, they are safer with a reduced health risk, less costly and provide additional nutritional benefits as a source of essential amino acids $[9,10]$. 
Peptides inhibit the angiotensin-converting enzyme (ACE) in different ways. While some remain intact upon reaction with ACE, others are degraded by ACE and based on the structure, size and amino acid composition of the new peptides generated, their antihypertensive activity will be lower, higher or equal in comparison to their parent peptides. Hence, peptides are classified into three categories based on the alterations in their antihypertensive activity after hydrolysis by ACE, which include substrate type, true inhibitor type and pro-drug type [10,11].

Despite the available literature on different approaches for the production and isolation as well as on the bioavailability and bio-accessibility of food-derived bioactive peptides, there is still limited information and knowledge on the structure-function relationship, ACE inhibition kinetics study and the mechanism of actions of antihypertensive peptides. The structure-function relationships study gives information on how the amino acid composition of peptide sequences (as substrate) and ACE (as an enzyme) interact together and affect the overall ACE inhibitory activity. Additionally, the kinetics parameters such as $\mathrm{K}_{\mathrm{m}}, \mathrm{V}_{\max }$ and catalytic efficiency (CE) are calculated to determine the optimal peptide dosage which exhibits maximum ACE inhibitory activity [12,13]. Moreover, the mode of inhibition between ACE-peptide interactions is determined using Michaelis-Menten and Lineweaver-Burk plots obtained from kinetics studies.

Molecular docking study is performed mainly to investigate the binding mode between target-ligand interaction. Docking is a computer-based method that predicts the affinity and binding conformation of a small molecule ligand (an inhibitor) to the appropriate target binding site (an enzyme) in order to determine and evaluate the hydrogen bond, hydrophobic interaction, electrostatic interactions, Van der Waals interaction force and total energy between peptide and ACE [14,15]. Recently, in silico molecular docking has been used to study the interaction between inhibitory peptides and ACE in pistachio hydrolysate [15], Salmo salar [16], milk protein [17], hemp seed [12] and stone fish hydrolysates [18].

To our knowledge, there is no report on the inhibitory interaction between papain-generated bioactive peptides and ACE. Therefore, in the present study, interaction between ACE and three novel bioactive peptides of sequences YLLLK, WAFS and GVQEGAGHYALL, generated from palm kernel cake protein $[19,20]$, is investigated. Peptides are then classified into substrate, prodrug and true inhibitor type, based on their stability against ACE. Inhibition kinetics study on the interaction between $A C E$ and the peptides is also carried out to determine $K_{m}, V_{\max }, K_{i}$, and CE and mode of inhibition. Moreover, in silico molecular docking study for the interaction between ACE and each of the three bioactive peptides is performed.

\section{Materials and Methods}

\subsection{Chemicals}

Hydrochloric acid, pyridine, benzene sulfonyl chloride (BSC) and trifluoroacetic acid (TFA) were purchased from Fisher Scientific (Atlanta, GA, USA). Angiotensin-I-converting enzyme (rabbit lung), captopril and Hippuryl-1-Histidyl-1-Leucine (HHL) were obtained from Sigma Chemical Co., (St Louis, MO, USA). Sodium chloride, boric acid and sodium borate were purchased from Merck Co. (Darmstadt, Hesse, Germany). Peptide sequences YLLLK, WAFS and GVQEGAGHYALL were identified in the papain-generated protein hydrolysate from palm kernel cake (PKC) after fractionation and then were synthesized (First Base Laboratories Sdn Bhd, Selangor, Malaysia) to be used in this study.

\subsection{Peptide Stability Study}

Peptide stability study was carried out using the method described by Forghani et al. [21] and Yang, Marczak, Yokoo, Usui and Yoshikawa [22] with modifications. Each peptide solution $(225 \mu \mathrm{L})$, at a concentration of $4 \mathrm{mM}$, was incubated with $150 \mu \mathrm{l}$ of ACE $(100 \mathrm{mU} / \mathrm{mL})$ at $37^{\circ} \mathrm{C}$ and incubation time of $0,0.5,1,2$ and $3 \mathrm{~h}$. Peptide samples were withdrawn at their respective incubation time separately and kept in ice prior to analysis by HPLC. A $20-\mu \mathrm{L}$ sample was loaded onto a Hypersil 
GOLD C18 column $(4.6 \times 250 \mathrm{~mm})$ attached to a LC 20AT apparatus (Shimadzu Co., Kyoto, Japan). The column was conditioned with eluent A (0.1\% TFA in DW) and eluted with $100 \%$ eluent A from 0 to $10 \mathrm{~min}$. The peptides were eluted with eluent $\mathrm{B}\left(0.1 \%\right.$ TFA in $\left.\mathrm{CH}_{3} \mathrm{CN}\right)$ with a gradient elution of $0-100 \%$ for $10-50 \mathrm{~min}$. The absorbance was read at $215 \mathrm{~nm}$.

\subsection{Kinetics Study of ACE Inhibition}

Mode of enzyme inhibition, maximum initial velocity $\left(\mathrm{V}_{\max }\right)$, Michaelis-Menten constant $\left(\mathrm{K}_{\mathrm{m}}\right)$, inhibitory constant $(\mathrm{Ki})$ and catalytic efficiency were determined using Michaeles-Menten and Lineweaver-Burk plots of $1 / \mathrm{v}$ versus $1 /[\mathrm{S}]$. ACE inhibition of peptides YLLLK, WAFS and GVQEGAGHYALL was determined in the presence of five concentrations of HHL including 0.5, 1, 2 and $8 \mathrm{mM}$ and four concentrations of peptides in the range of 31 to $2000 \mu \mathrm{M}$ (Table 1).

Table 1. Peptide concentrations used for kinetic study.

\begin{tabular}{lccccc}
\hline & Peptides & \multicolumn{4}{c}{ Peptide Concentration $(\mu \mathbf{M})$} \\
\hline 1 & YLLLK & 250.0 & 125.0 & 62.0 & 31.0 \\
2 & WAFS & 2000 & 1000 & 500 & 62.0 \\
3 & GVQEGAGHYALL & 250.0 & 125.0 & 62.0 & 31.0 \\
\hline
\end{tabular}

Enzyme activity was shown as nmol hippuric acid produced per min of enzymatic reaction. Michaelis-Menten and Lineweaver-Burk plots were created using GRAPHPAD PRISM 6.07 (GraphPad, Software Inc., San Diego, CA, USA) software. Vmax and Km were calculated using the same software. $\mathrm{K}_{\mathrm{iu}}$ was calculated from the plot of $1 / \mathrm{Vmax}$ against inhibitor concentration at the intercept on the inhibitor concentration axis [23]).

\subsection{Molecular Docking Studies}

Molecular docking was conducted using Glide (Glide, version 6.7, Schrödinger, LLC, New York, NY, 2015). The structures of YLLLK, WAFS and GVQEGAGHYALL were generated using Molecular Operating Environment software (MOE 2014.0901, Chemical Computing Group, Inc., Montreal, QC, Canada, 2014), and the energies were minimized using MMFF94 program. For ACE docking, a crystal structure of human ACE bound to captopril as the ACE-inhibitory drug (PDB ID 1UZF) was employed as an ACE model molecule. A binding site was generated by digitally removing captopril within a radius of $20 \AA$, with the coordinates $x=36.98, y=27.05$, and $z=50.65$. Glide extra precision (XP) docking was performed for all the ACE inhibitory peptides using captopril as a benchmark. All water molecules in the structure of protein were digitally detached, and hydrogen atoms were added to the structure of the protein. Binding energy values and the scores were used to evaluate the molecular docking to determine the best poses for each of the peptides. The binding affinity between the ACE and peptides were determined and reported as negative values of Glide scores ( $\mathrm{kcal} / \mathrm{mol})$. The Glide scores $(\mathrm{kcal} / \mathrm{mol})$ are shown as negative values, and those positions with a more negative value exhibit a potent interaction between protein and ligand. The Glide pose viewer was employed to analyze the resulting docked poses and to detect the hydrogen bonds and the hydrophobic, hydrophilic, electrostatic, and coordination interactions between the ACE and peptides. The best docking poses with low Glide scores and the least binding energy were subjected to further analysis.

\subsection{Statistical Analysis}

The statistical analysis was carried out using Minitab 16.0 software (MINITAB, State College, PA, USA). All experiments were performed in triplicate. Data are presented as mean \pm standard deviation from at least triplicate determinations. Analysis was carried out using one-way analysis of variance (ANOVA). Statistically significant differences among means of experimental design were studied by Tukey multiple range tests at $p=0.05$ using MINITAB RELEASE 16 . 


\section{Results and Discussion}

\subsection{Effect of the Catalytic Activity of Angiotensin Converting Enzyme on Bioactive Peptides}

From HPLC chromatograms, YLLLK showed that the number of peaks was 1 at the first $30 \mathrm{~min}$ with $91.7 \%$ of peptide cleavage and finally it decreased to 4 peaks in $3 \mathrm{~h}$ of pre-incubation with $94.3 \%$ cleavage, while WAFS and GVQEGAGHYALL showed 3 and 6 peaks, respectively, throughout 3 h of incubation. Furthermore, the percentage cleavage for WAFS and GVQEGAGHYALL was $43 \%$ and $46 \%$ in the first $30 \mathrm{~min}$ of incubation time and $68 \%$ and $97 \%$, respectively after $3 \mathrm{~h}$ of incubation time, implying that none of these peptides is resistant to ACE, thus eliminating the possibility of "true inhibitor" (Figure 1 and Table 2).

Table 2. Hydrolysis of papain-generated peptides by angiotensin-converting enzyme (ACE) with incubation for $3 \mathrm{~h}$.

\begin{tabular}{ccccccc}
\hline \multicolumn{7}{c}{ Bioactive Peptides } \\
\hline \multirow{2}{*}{$\begin{array}{c}\text { Incubation } \\
\text { Time (h) }\end{array}$} & \multicolumn{2}{c}{ YLLLK } & & WAFS & \multicolumn{2}{c}{ GVQEGAGHYALL } \\
\cline { 2 - 6 } & Peaks & Cleavage (\%) & Peaks & Cleavage (\%) & Peaks & Cleavage (\%) \\
\hline 0.5 & 2 & $92 \pm 2.8$ & 3 & $43 \pm 2.0$ & 6 & $46 \pm 1.5$ \\
1 & 4 & $93 \pm 1.9$ & 3 & $42 \pm 1.6$ & 6 & $65 \pm 2.6$ \\
2 & 3 & $94 \pm 3.0$ & 3 & $63 \pm 3.0$ & 6 & $86 \pm 3.1$ \\
3 & 2 & $94 \pm 2.7$ & 3 & $68 \pm 3.4$ & 6 & $97 \pm 3.4$ \\
\hline
\end{tabular}

In a study performed by Skidgel and Erdös [24], they proposed that Substance P, a neuropeptide with the sequence of RPKPQQFFGLM, can be cleaved by ACE from the penultimate residue with the removal of LM from the sequence since ACE is a peptidyl dipeptidase that removes C-terminal dipeptides from its substrates, such as bradykinin and angiotensin I [25,26]. Therefore, it degraded peptide RPKPQQFFGLM into two fractions of RPKPQQFFG and LM. Similarly, YLLLK also has been degraded by ACE into YLL and LK. Moreover, in another research, Rao, et al. [27] studied the effect of ACE on a synthesized peptide, IKPFR, and they observed that it was degraded into two fragments of IKP and FR. It seems that peptide WAFS also was degraded into two sequences of WA and FS due to having a phenylalanine (F) residue in the second position of the peptide sequence from its C-terminus. It was shown that bradykinin, which contains a phenylalanine residue at the second position from C-terminus, was broken into two fragments of RPPGFSP and FR [28], which supported the observation in the current study.

It seems that peptide GVQEGAGHYALL has been degraded by ACE at different positions. Similar results have been obtained from incubation of ACE with different substrates such as Substance P [24], RMLGQTPTK [29] and FKGRYYP [30], suggesting that ACE can degrade the sequences containing the amino acid residues $\mathrm{L}, \mathrm{Y}$ and $\mathrm{G}$ in their structure.

Peptide YLLLK showed 100\% ACE inhibitory activity before pre-incubation whereas the ACE inhibitory activity dropped to $80 \%$ after pre-incubation with ACE. Peptides WAFS and GVQEGAGHYALL showed higher ACE inhibitory activity after pre-incubation, suggesting that peptide YLLLK as a substrate type inhibitor whereas peptides WAFS and GVQEGAGHYALL are pro-drug type inhibitors due to higher ACE inhibitory activity after pre-incubation (Table 3).

Table 3. ACE-inhibitory capacities (\%) of peptides with and without pre-incubation with ACE.

\begin{tabular}{cccc}
\hline \multirow{2}{*}{ Peptides } & \multicolumn{2}{c}{ ACE-Inhibitory Capacity (\%) } & \\
\cline { 2 - 3 } & Without Pre-Incubation & $\begin{array}{c}\text { With } \\
\text { Pre-Incubation }\end{array}$ & Classification \\
\hline YLLLK & $100 \pm 2.99$ & $80 \pm 2.04$ & Substrate type \\
WAFS & $55 \pm 1.81$ & $56 \pm 1.34$ & Pro-drug inhibitor \\
GVQEGAGHYALL & $70 \pm 1.15$ & $75 \pm 2.11$ & Pro-drug inhibitor \\
\hline
\end{tabular}



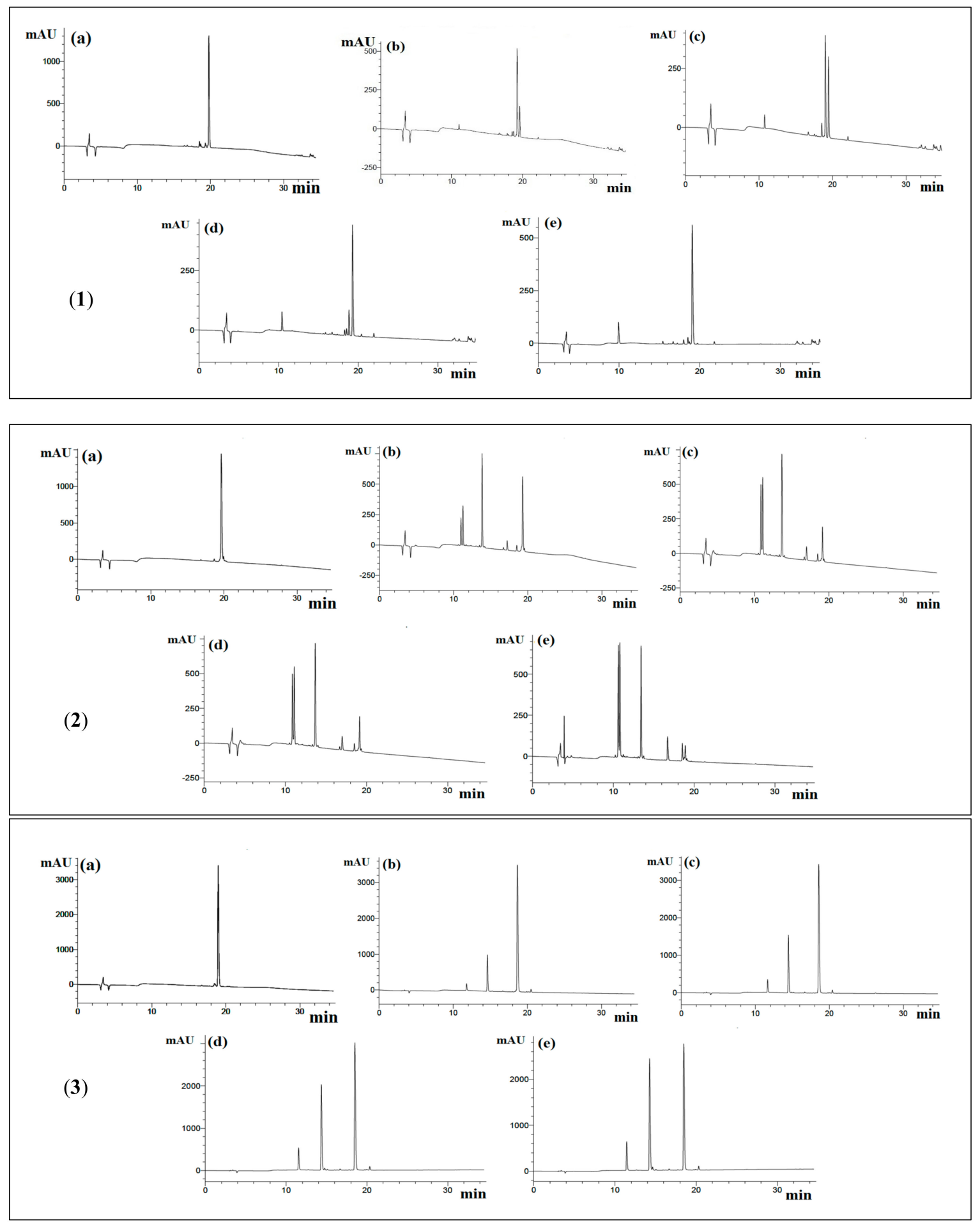

Figure 1. Reversed-phase high performance liquid chromatography (RP-HPLC) chromatograms of hydrolysis of peptides by ACE. (1) YLLLK; (2) WAFS (3) GVQEGAGHYALL; (a) before incubation; (b) $0.5 \mathrm{~h}$ of incubation; (c) $1 \mathrm{~h}$ of incubation; (d) $2 \mathrm{~h}$ of incubation; (e) $3 \mathrm{~h}$ of incubation. $20 \mu \mathrm{L}$ of sample was eluted by mobile phase A $(0.1 \%$ of TFA in deionized water) and $0-60 \%$ gradient of mobile phase B $\left(0.1 \%\right.$ of TFA in $\left.\mathrm{CH}_{3} \mathrm{CN}\right)$ for $5-35$ min on a C18 column.

\subsection{Inhibition Kinetics of Bioactive Peptides toward ACE}

Lineweaver-Burk and Michaelis-Menten plots were used to determine the inhibition kinetics of YLLLK, WAFS and GVQEGAGHYALL. The calculated $\mathrm{K}_{\mathrm{m}}$ (Michaelis constant), $\mathrm{V}_{\max }$ (maximum 
reaction velocity), $C E$ (catalytic efficiency) and $\mathrm{K}_{\mathrm{iu}}$ (enzyme-inhibitor dissociation constant) values for the bioactive peptides are summarized in Table 4.

The $\mathrm{K}_{\mathrm{m}}$ value for angiotensin-converting enzyme activity in the absence of inhibiting peptides YLLLK, WAFS and GVQEGAGHYALL was around 1.458, while in the presence of these peptides at the concentrations of 31 to $250 \mu \mathrm{M}, 62$ to $2000 \mu \mathrm{M}$ and 31 to $250 \mu \mathrm{M}, K_{\mathrm{m}}^{\text {app }}$ was calculated between 0.3257 to $1.7820 \mathrm{mM}, 2.807$ to $5.712 \mathrm{mM}$ and 1.890 to $2.856 \mathrm{mM}$, respectively. As shown, the $\mathrm{K}_{\mathrm{m}}$ value for $\mathrm{ACE}$ activity alone was lower than $K_{\mathrm{m}}^{\mathrm{app}}$ for ACE in the presence of peptides, indicating that the ACE reaction requires more substrate for catalysis in the presence of peptides WAFS and GVQEGAGHYALL at all concentrations and YLLLK only at concentration of $31 \mu \mathrm{M}$. The $K_{\mathrm{m}}^{\text {app }}$ value for concentration of 62 , 125 and $250 \mu \mathrm{M}$ in the presence of peptide YLLLK was lower than the $\mathrm{K}_{\mathrm{m}}$ value of ACE in the absence of YLLLK.

The $K_{\mathrm{m}}^{\mathrm{app}}$ value reduced when concentration of peptides YLLLK and GVQEGAGHYALL increased, implying that at higher peptide levels, more peptides become bound to the enzyme active site to prevent the formation of an enzyme-substrate complex.

The $V_{\text {max }}$ for uninhibited ACE was $31 \mathrm{nmol} / \mathrm{min}$. In the presence of three peptides, $V_{\text {max }}$ decreased when peptide concentrations increased. Therefore, the results revealed that the activation energy was increased in the presence of the peptides because the velocity of the enzyme reaction was decelerated. This result is in agreement with that reported by Girgih, He and Aluko [12] and Forghani, Zarei, Ebrahimpour, Philip, Bakar, Abdul Hamid and Saari [21]. In particular, peptide YLLLK showed lower $V_{\max }^{\mathrm{app}}$ in comparison to the other two peptides at all concentrations, which is in agreement with its lower $\mathrm{IC}_{50}(47 \mu \mathrm{M})$ and higher ACE inhibitory activity.

Furthermore, kinetic studies showed that the inhibition mode of YLLLK, WAFS and GVQEGAGHYALL, at different concentrations, was mixed-type inhibition because the $x$-axis and slope lines of Lineweaver-Burk plots do not intersect at the same point and the $\mathrm{K}_{\mathrm{m}}$ values of the control and various peptide concentrations were different (Figure 2). This demonstrates that the peptides can bind both to the free enzyme as well as to the ES complex.

Table 4. $V_{\max }, K_{\mathrm{m}}$ of ACE inhibited by peptides along with its $K_{\mathrm{iu}}$ and CE.

\begin{tabular}{|c|c|c|c|c|c|c|c|}
\hline $\begin{array}{l}\text { Peptide } \\
\text { Sequence }\end{array}$ & $\begin{array}{c}\text { Peptide } \\
\text { Concentration } \\
(\mu \mathrm{M})\end{array}$ & $\begin{array}{c}K_{\mathrm{m}} \\
(\mathrm{mM})\end{array}$ & $\underset{(\mathrm{nmol} / \mathrm{min})}{V_{\max }}$ & $\begin{array}{c}K_{\mathrm{m}}^{\mathrm{app}} \\
(\mathrm{mM})\end{array}$ & $\begin{array}{c}V_{\max }^{\mathrm{app}} \\
(\mathrm{nml} / \mathrm{min})\end{array}$ & $\begin{array}{c}C E \\
\left(V_{\max }^{\text {app }} / K_{\mathrm{m}}^{\text {app }}\right)\end{array}$ & $\begin{array}{c}K_{\mathrm{iu}} \\
(\mathrm{mM})\end{array}$ \\
\hline \multirow{4}{*}{ YLLLK } & 250 & & & 0.3257 & 11.19 & 34.35 & \multirow{4}{*}{0.155} \\
\hline & 125 & & & 0.6862 & 14.21 & 20.70 & \\
\hline & 62.0 & & & 1.2430 & 25.72 & 20.69 & \\
\hline & 31.0 & & & 1.7820 & 25.88 & 14.52 & \\
\hline \multirow{2}{*}{ Control } & 0.00 & 1.452 & 31.67 & & & 21.81 & \multirow{5}{*}{2} \\
\hline & 2000 & & & 2.807 & 33.63 & 11.98 & \\
\hline \multirow{3}{*}{ WAFS } & 1000 & & & 5.712 & 56.81 & 9.94 & \\
\hline & 500 & & & 5.051 & 59.79 & 11.83 & \\
\hline & 62.0 & & & 3.455 & 61.03 & 17.66 & \\
\hline \multirow[t]{2}{*}{ Control } & 0.00 & 1.456 & 31.87 & & & 21.88 & \multirow{6}{*}{3.18} \\
\hline & 250 & & & 1.890 & 32.83 & 17.37 & \\
\hline \multirow{3}{*}{ GVQEGAGHYALL } & 125 & & & 1.973 & 37.77 & 19.14 & \\
\hline & 62.0 & & & 2.483 & 47.69 & 19.20 & \\
\hline & 31.0 & & & 2.856 & 54.68 & 19.14 & \\
\hline Control & 0.00 & 1.493 & 32.39 & & & 21.69 & \\
\hline
\end{tabular}

The catalytic efficiency (CE) of uninhibited ACE reaction for YLLLK, WAFS and GVQEGAGHYALL was 21.81, 21.88 and 22.69, respectively. These peptides demonstrated lower CE values in all peptide concentrations compared to uninhibited ACE, except concentration of $250 \mu \mathrm{M}$ for YLLLK, indicating that enzyme catalysis was lower in the presence of peptides compared to that in the absence of peptides. Thus, the peptides demonstrated some binding affinity to the enzyme, which led to reduced catalytic ability and consequently reduced their $V_{\max }^{\text {app }}$ and $\mathrm{IC}_{50}$ values. Peptide YLLLK showed the lowest $\mathrm{K}_{\mathrm{iu}}$ $(0.155 \mathrm{mM})$ compared to the peptides WAFS and GVQEGAGHYALL with $\mathrm{K}_{\mathrm{iu}} 2 \mathrm{mM}$ and $3.18 \mathrm{mM}$, 
respectively. The lower $K_{i u}$ value for YLLLK is consistent with the observed greater reductions in $V_{\max }$ and CE when compared to the reductions produced by WAFS and GVQEGAGHYALL. The $K_{\text {iu }}$ value obtained for peptide YLLLK $(0.155 \mathrm{mM})$ was lower than the $\mathrm{K}_{\text {iu }}$ value of CRQNTLGHNTQTSIAQ $(0.21 \mathrm{mM})$, VSRHFASYAN $(0.61 \mathrm{mM})$, SAAVGSP $(1.57 \mathrm{mM})$ generated from Stichopus horrens [21] and TF $(12.2726 \mathrm{mM})$. However, it was higher than WVYY $(0.06 \mathrm{mM})$, which was previously reported by Udenigwe, et al. [31]. Peptide GVQEGAGHYALL showed the highest $\mathrm{K}_{\mathrm{iu}}(3.18 \mathrm{mM})$ compared to peptides YLLLK and WAFS, indicating that this peptide has the lowest affinity towards ACE in this study. This peptide also showed the highest $\mathrm{IC}_{50}(239 \mu \mathrm{M})$ among three peptides.
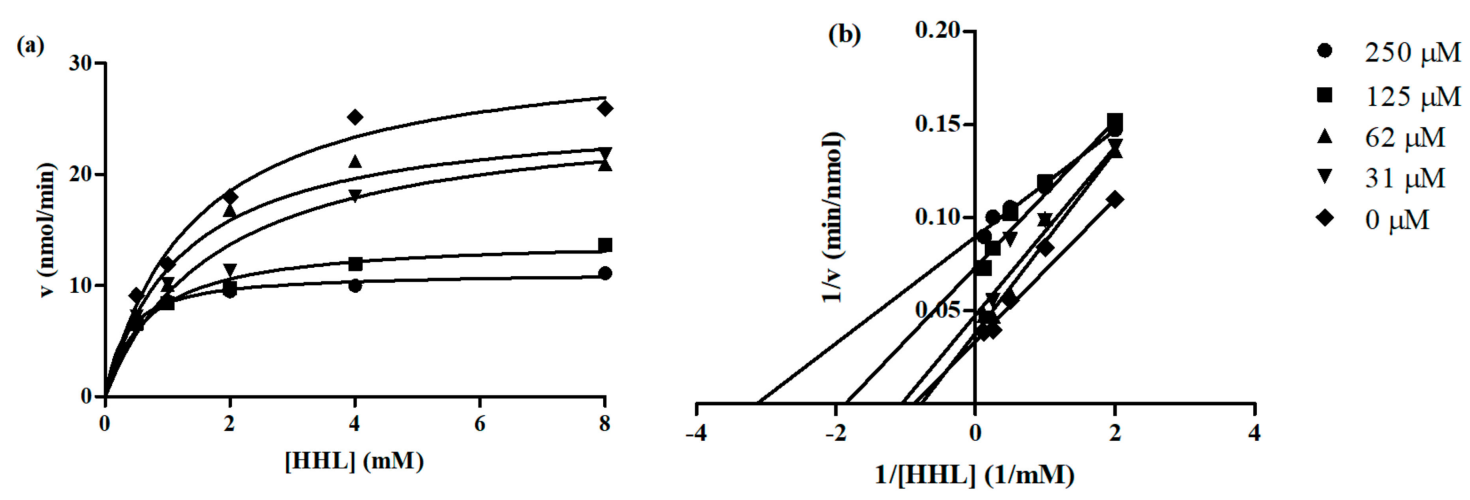

(1)
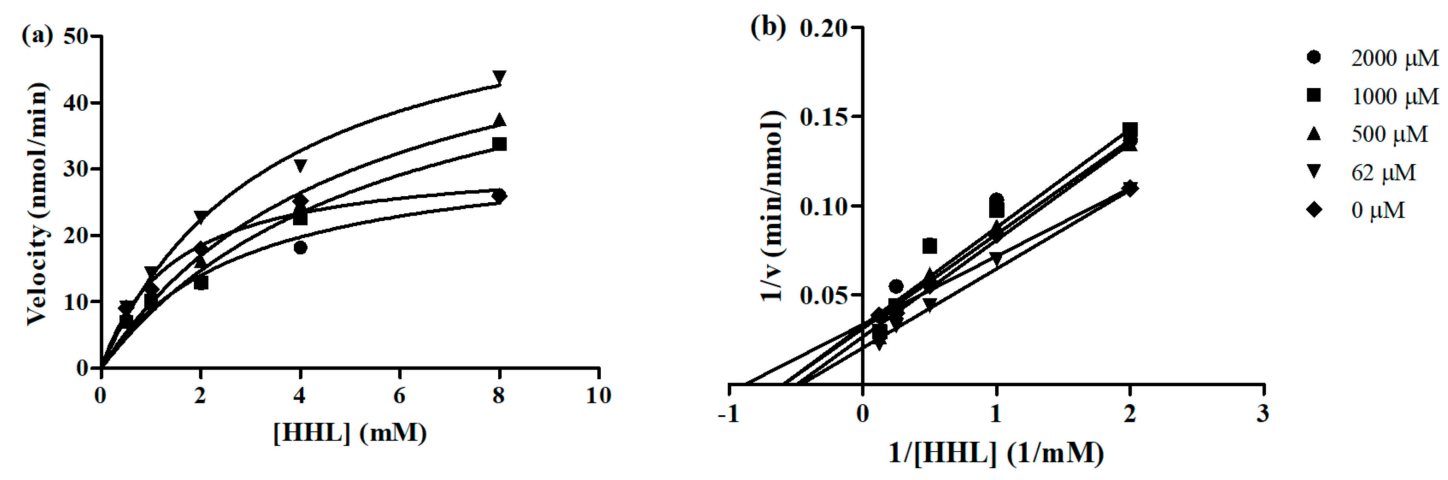

(2)
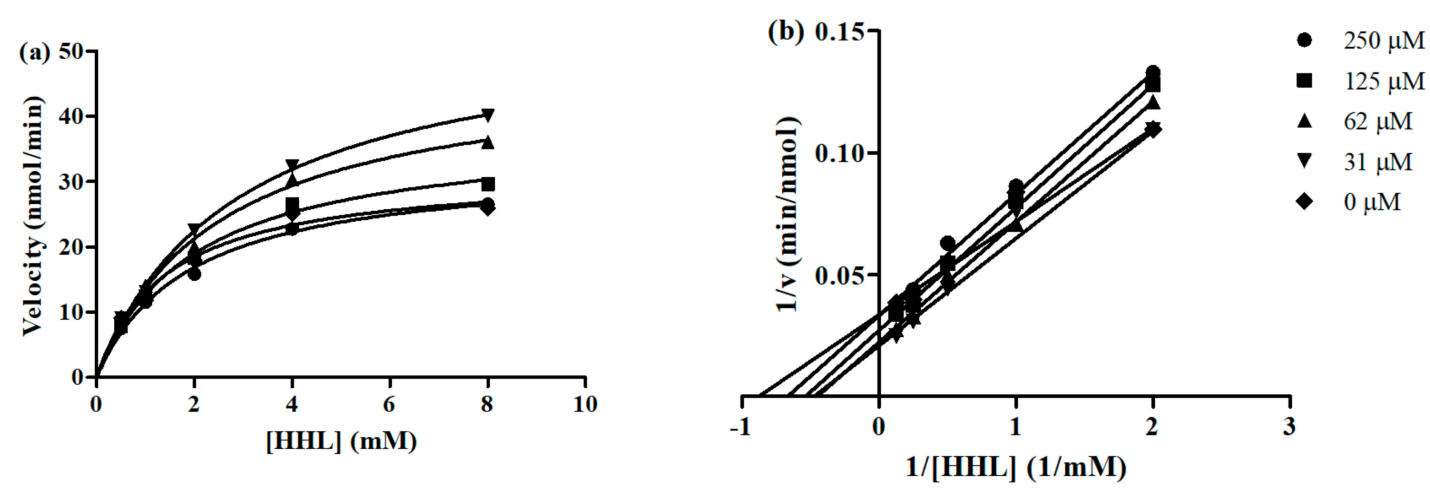

(3)

Figure 2. (a) Michaelis-Menten and (b) Lineweaver-Burk plot of peptides. Each point represents the mean of three experiments. ACE activities measured in the absence or presence of peptides. (1) YLLLK; (2) WAFS and (3) GVQEGAGHYALL. 


\subsection{Molecular Docking Studies}

Figure 3 indicates the presence of the best poses for YLLLK, WAFS and GVQEGAGHYALL within the catalytic site of ACE. The stability of the best pose for each peptide was achieved through hydrogen bonding, electrostatic and hydrophobic interactions between amino acid residues of the ACE binding domain and those of the individual peptide within a distance of $3.5 \AA$. YLLLK exhibited the higher number of total interactions (7) with ACE, which could be the main reason for the higher ACE inhibitory activity (lower $\mathrm{IC}_{50}$ value of $47 \mu \mathrm{M}$ ) compared to WAFS and GVQEGAGHYALL, which have five interactions each. This was ascertained by the lowest electrostatic binding energy of $-122.247 \mathrm{~kJ} / \mathrm{mol}$ for YLLLK compared to $-115.733 \mathrm{~kJ} / \mathrm{mol}$ for WAFS and $-115.0981 \mathrm{~kJ} / \mathrm{mol}$ for GVQEGAGHYALL, as shown in Table 5. Similarly, the van der Waals energy of $-4.115 \mathrm{~kJ} / \mathrm{mol}$ for YLLLK was lower compared to WAFS $(-2.267 \mathrm{kj} / \mathrm{mol})$ and GVQEGAGHYALL $(-1.396 \mathrm{~kJ} / \mathrm{mol})$. As shown in Table 4 , the binding energy data revealed the higher ACE-binding affinity (lower $K_{i}$ value of $0.155 \mathrm{mM}$ ) of YLLLK compared to WAFS and GVQEGAGHYALL with 2 and $3.18 \mathrm{mM}$, respectively. The higher activity of YLLLK may also be due to a higher degree of interactions with the active site of ACE. As shown in Table 5, it appears that the ability of peptides to develop numerous hydrogen bond interactions with ACE may be a major factor in the ACE inhibitory activity of the peptide and stabilization of the ACE-peptide complex structure.

Table 5. ACE inhibitory activities and docking study characteristics of peptides.

\begin{tabular}{cccc}
\hline & YLLLK & WAFS & GVQEGAGHYALL \\
\hline ACE Inhibition (\%) & 100 & 55 & 70 \\
ACE Inhibition (IC 50 ) & 47 & 202 & 239 \\
Electrostatic interaction $(\mathrm{kJ} / \mathrm{mol})$ & -122.247 & -115.733 & -115.098 \\
Hydrophobic interaction $(\mathrm{kJ} / \mathrm{mol})$ & -1.048 & -0.535 & -0.512 \\
Van der Waals $(\mathrm{kJ} / \mathrm{mol})$ & -4.115 & -2.267 & -1.396 \\
Docking Score & -8.224 & -7.611 & -7.600 \\
H-bonds & 7 & 5 & 5 \\
Total Interaction & 15 & 15 & 13 \\
\hline
\end{tabular}

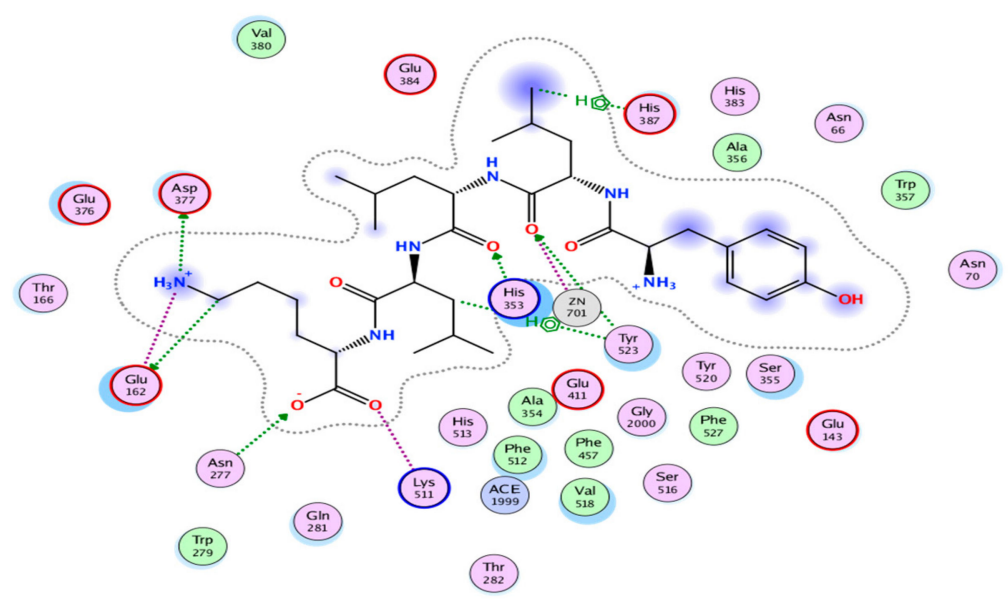

(A)

Figure 3. Cont. 


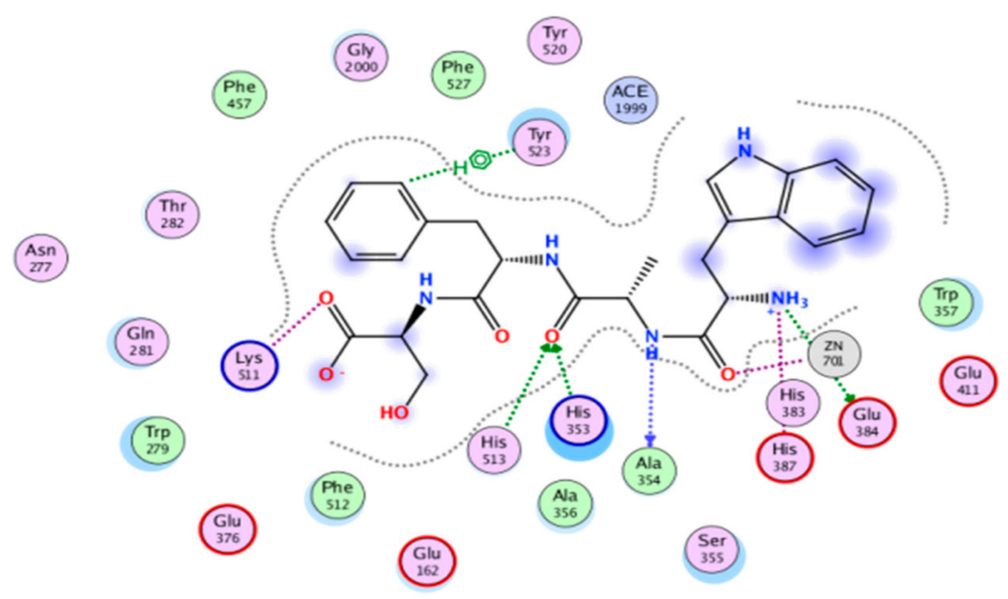

(B)

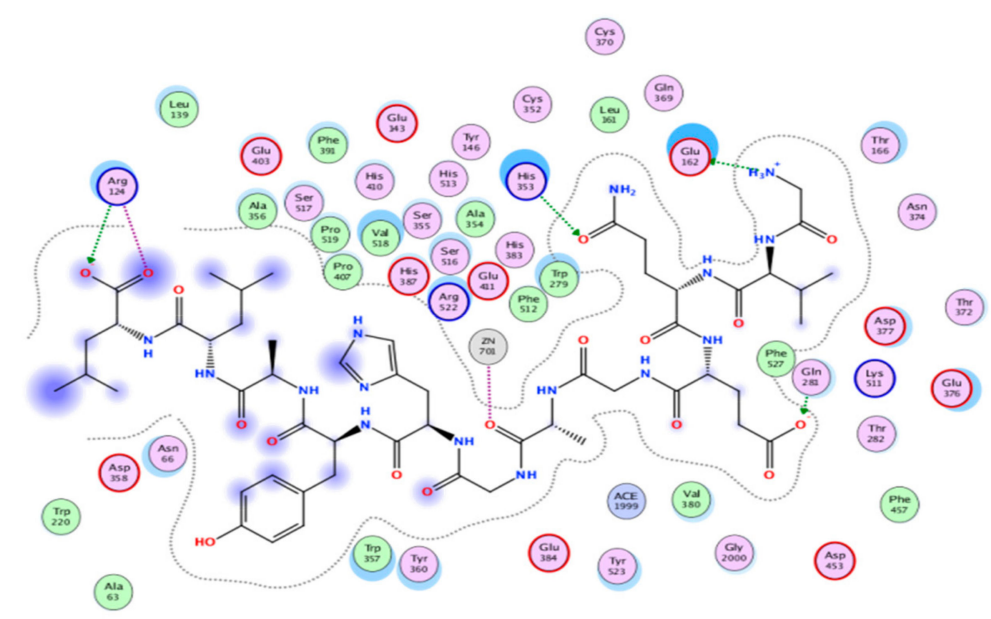

(C)

Figure 3. Automated molecular docking of YLLLK (A), WAFS (B), and GVQEGAGHYALL (C) at the angiotensin-converting enzyme (ACE) active site. ACE hydrophobic residues are represented in green, positively charged residues in blue, and negatively charged residues in red; hydrogen bonds are purple arrows, polar residues are in turquoise color, and other residues and the zinc atom are represented automatically. Image obtained with Accelrys DS Visualizer software.

A similar pattern of hydrogen bonds with ACE residues has been reported for peptides WVYY (7 bonds) and WYT (5 bonds) [12]. Furthermore, the $\mathrm{IC}_{50}$ is correlated to the number of hydrogen bonds formed. As shown in Table 5, YLLLK revealed the lowest $\mathrm{IC}_{50}$ of $47 \mu \mathrm{M}$ and formed $7 \mathrm{H}$-bonds, followed by WAFS, with an $\mathrm{IC}_{50}$ of $202 \mu \mathrm{M}$ and GVQEGAGHYALL with $239 \mu \mathrm{M}$. Thus, it appears that the number of hydrogen bonds and ACE residues involved play a prominent role in the ACE-inhibitory capacity of the peptides.

\section{Conclusions}

Interaction of ACE with three novel papain-generated bioactive peptides from palm kernel cake proteins, namely YLLLK, WAFS and GVQEGAGHYALL, was studied by molecular docking simulation. Furthermore, the inhibition kinetics and the stability of the peptides against ACE were studied. Lineweaver-Burk plots revealed that the inhibition mode of the peptides at different concentrations was mixed-type inhibition, implying that the peptides can compete with the substrate to bind to the active site of the enzyme and at other non-active sites. Moreover, peptide stability study showed that the peptides were degraded to different cleavage degrees upon pre-incubation with ACE. Additionally, results demonstrated that YLLLK was a substrate inhibitor, whereas peptides WAFS and 
GVQEGAGHYALL were prodrug inhibitors. Based on molecular docking study, YLLLK exhibited a higher number of total interactions in comparison to WAFS and GVQEGAGHYALL, which could be a reason for the lower $\mathrm{IC}_{50}$ of YLLLK.

Author Contributions: N.S. conceived and supervised the research from the start to the final compilation of the manuscript. M.Z. designed and performed the experiments as well as the analysis of data and writing of the manuscript. M.Z. carried out the data analysis. N.B.Z.A. performed the docking analysis section. S.M.A., S.Y.C., Z.A.H. and A.M.S. contributed in review and revision of the manuscript.

Funding: The authors are thankful for the funding support under the project No. 10-05-ABI-FB 037 by the grant from the Malaysian Ministry of Science, Technology, and Innovation.

Conflicts of Interest: The authors declare no conflict of interest.

\section{References}

1. Toldrá, F.; Reig, M.; Aristoy, M.C.; Mora, L. Generation of bioactive peptides during food processing. Food Chem. 2018, 267, 395-404. [CrossRef] [PubMed]

2. Auwal, S.M.; Zarei, M.; Tan, C.P.; Basri, M.; Saari, N. Enhanced physicochemical stability and efficacy of angiotensin I-converting enzyme (ACE) - inhibitory biopeptides by chitosan nanoparticles optimized using Box-Behnken design. Sci. Rep. 2018, 8, 10411. [CrossRef] [PubMed]

3. Zarei, M.; Ghanbari, R.; Tajabadi, N.; Abdul-Hamid, A.; Bakar, F.A.; Saari, N. Generation, Fractionation, and Characterization of Iron-Chelating Protein Hydrolysate from Palm Kernel Cake Proteins. J. Food Sci. 2016, 81, C341-C347. [CrossRef]

4. Auwal, S.M.; Zarei, M.; Abdul-Hamid, A.; Saari, N. Optimization of Bromelain-Aided Production of Angiotensin I-Converting Enzyme Inhibitory Hydrolysates from Stone Fish Using Response Surface Methodology. Mar. Drugs 2017, 15, 104. [CrossRef] [PubMed]

5. Qiao, M.; Tu, M.; Wang, Z.; Mao, F.; Chen, H.; Qin, L.; Du, M. Identification and Antithrombotic Activity of Peptides from Blue Mussel (Mytilus edulis) Protein. Int. J. Mol. Sci. 2018, 19, 138. [CrossRef]

6. González-Montoya, M.; Hernández-Ledesma, B.; Silván, J.M.; Mora-Escobedo, R.; Martínez-Villaluenga, C. Peptides derived from in vitro gastrointestinal digestion of germinated soybean proteins inhibit human colon cancer cells proliferation and inflammation. Food Chem. 2018, 242, 75-82. [CrossRef] [PubMed]

7. Lin, Q.; Liao, W.; Bai, J.; Wu, W.; Wu, J. Soy protein-derived ACE-inhibitory peptide LSW (Leu-Ser-Trp) shows anti-inflammatory activity on vascular smooth muscle cells. J. Funct. Foods 2017, 34, 248-253. [CrossRef]

8. Reyes-Díaz, A.; González-Córdova, A.F.; Hernández-Mendoza, A.; Reyes-Díaz, R.; Vallejo-Cordoba, B. Immunomodulation by hydrolysates and peptides derived from milk proteins. Int. J. Dairy Technol. 2018, 71, 1-9. [CrossRef]

9. Iwaniak, A.; Minkiewicz, P.; Darewicz, M. Food-originating ace inhibitors, including antihypertensive peptides, as preventive food components in blood pressure reduction. Compr. Rev. Food Sci. Food Saf. 2014, 13, 114-134. [CrossRef]

10. Norris, R.; FitzGerald, R.J. Antihypertensive Peptides from Food Proteins. In Bioactive Food Peptides in Health and Disease; Blanca, H.L., Chia, C.H., Eds.; InTechOpen Publishers: London, UK, 2013; p. 45.

11. Matsui, T.; Matsumoto, K. Antihypertensive peptides from natural resources. Adv. Phytomedicine 2006, 2, 255-271.

12. Girgih, A.T.; He, R.; Aluko, R.E. Kinetics and Molecular Docking Studies of the Inhibitions of Angiotensin Converting Enzyme and Renin Activities by Hemp Seed (Cannabis sativa L.) Peptides. J. Agric. Food Chem. 2014, 62, 4135-4144. [CrossRef]

13. He, R.; Aluko, R.E.; Ju, X.-R. Evaluating Molecular Mechanism of Hypotensive Peptides Interactions with Renin and Angiotensin Converting Enzyme. PLoS ONE 2014, 9, e91051. [CrossRef] [PubMed]

14. Hetényi, C.; van der Spoel, D. Efficient docking of peptides to proteins without prior knowledge of the binding site. Protein Sci. 2002, 11, 1729-1737. [CrossRef] [PubMed]

15. Li, P.; Jia, J.; Fang, M.; Zhang, L.; Guo, M.; Xie, J.; Xia, Y.; Zhou, L.; Wei, D. In vitro and in vivo ACE inhibitory of pistachio hydrolysates and in silico mechanism of identified peptide binding with ACE. Process Biochem. 2014, 49, 898-904. [CrossRef] 
16. Yu, Z.; Chen, Y.; Zhao, W.; Li, J.; Liu, J.; Chen, F. Identification and molecular docking study of novel angiotensin-converting enzyme inhibitory peptides from Salmo salar using in silico methods. J. Sci. Food Agric. 2018, 98, 3907-3914. [CrossRef] [PubMed]

17. Pan, D.; Guo, H.; Zhao, B.; Cao, J. The molecular mechanisms of interactions between bioactive peptides and angiotensin-converting enzyme. Bioorganic Med. Chem. Lett. 2011. [CrossRef] [PubMed]

18. Auwal, S.M.; Abidin, N.Z.; Zarei, M.; Tan, C.P.; Saari, N. Identification, structure-activity relationship and in silico molecular docking analyses of five novel angiotensin I-converting enzyme (ACE)-inhibitory peptides from stone fish (Actinopyga lecanora) hydrolysates. PLoS ONE 2019, 14, e0197644. [CrossRef] [PubMed]

19. Zarei, M.; Forghani, B.; Ebrahimpour, A.; Abdul-Hamid, A.; Anwar, F.; Saari, N. In vitro and in vivo antihypertensive activity of palm kernel cake protein hydrolysates: Sequencing and characterization of potent bioactive peptides. Ind. Crop. Prod. 2015, 76, 112-120. [CrossRef]

20. Zarei, M.; Ebrahimpour, A.; Abdul-Hamid, A.; Anwar, F.; Bakar, F.A.; Philip, R.; Saari, N. Identification and characterization of papain-generated antioxidant peptides from palm kernel cake proteins. Food Res. Int. 2014, 62, 726-734. [CrossRef]

21. Forghani, B.; Zarei, M.; Ebrahimpour, A.; Philip, R.; Bakar, J.; Abdul Hamid, A.; Saari, N. Purification and characterization of angiotensin converting enzyme-inhibitory peptides derived from Stichopus horrens: Stability study against the ACE and inhibition kinetics. J. Funct. Foods 2016, 20, 276-290. [CrossRef]

22. Yang, Y.; Marczak, E.D.; Yokoo, M.; Usui, H.; Yoshikawa, M. Isolation and antihypertensive effect of angiotensin I-converting enzyme (ACE) inhibitory peptides from spinach Rubisco. J. Agric. Food Chem. 2003, 51, 4897-4902. [CrossRef] [PubMed]

23. Cornish-Bowden, A.; Cárdenas, M.L. Control of Metabolic Processes; Springer Science \& Business Media: Boston, MA, USA, 2013; p. 190.

24. Skidgel, R.A.; Erdös, E.G. The broad substrate specificity of human angiotensin I converting enzyme. Clin. Exp. Hypertens. Part A: Theory Pr. 1987, 9, 243-259. [CrossRef] [PubMed]

25. Erdös, E.; Skidgel, R. Structure and functions of human angiotensin I converting enzyme (kininase II). Biochem. Soc. Trans. 1985, 13, 42-44. [CrossRef] [PubMed]

26. Henriksen, J.H. Degradation of Bioactive Substances: Physiology and Pathophysiology; CRC Press: Boca Raton, FL, USA, 1991.

27. Rao, S.-Q.; Liu, S.; Ju, T.; Xu, W.-Q.; Mei, G.-M.; Xu, Y.-S.; Yang, Y.-J. Design of substrate-type ACE inhibitory pentapeptides with an antepenultimate C-terminal proline for efficient release of inhibitory activity. Biochem. Eng. J. 2012, 60, 50-55. [CrossRef]

28. Ehlers, M.R.; Riordan, J.F. Angiotensin-converting enzyme: New concepts concerning its biological role. Biochemistry 1989, 28, 5311-5318. [CrossRef] [PubMed]

29. Katayama, K.; Tomatsu, M.; Fuchu, H.; Sugiyama, M.; Kawahara, S.; Yamauchi, K.; Kawamura, Y.; Muguruma, M. Purification and characterization of an angiotensin I-converting enzyme inhibitory peptide derived from porcine troponin C. Anim. Sci. J. 2003, 74, 53-58. [CrossRef]

30. Fujita, H.; Yoshikawa, M. LKPNM: A prodrug-type ACE-inhibitory peptide derived from fish protein. Immunopharmacology 1999, 44, 123-127. [CrossRef]

31. Udenigwe, C.C.; Lin, Y.-S.; Hou, W.-C.; Aluko, R.E. Kinetics of the inhibition of renin and angiotensin I-converting enzyme by flaxseed protein hydrolysate fractions. J. Funct. Foods 2009, 1, 199-207. [CrossRef]

(C) 2019 by the authors. Licensee MDPI, Basel, Switzerland. This article is an open access article distributed under the terms and conditions of the Creative Commons Attribution (CC BY) license (http://creativecommons.org/licenses/by/4.0/). 